\title{
Fen Bilimleri Öğretmeni Adaylarının Oryantasyon Programına Yönelik Görüşlerinin İncelenmesi
}

\author{
Emre Yıldız, Yeter Ünlü**
}

Makale Geliş Tarihi: 01/04/2020

Makale Kabul Tarihi: 17/10/2020

DOI: $10.35675 /$ befdergi.712496

$\ddot{O} z$

$B u$ araştırmanın amacı üniversite ögrenimine yeni başlayan fen bilimleri ögretmeni adaylarının oryantasyon programına yönelik görüşlerinin incelenmesidir. Araştırmada olgu bilim deseni benimsenmiştir. Oryantasyon programlarının tamamına katılan 13 ögretmen aday ile çalışılmıştır. Veriler açık uçlu görüşme formu ile toplanmıştır. Verilerin analizinde içerik analizi yöntemi kullanılmıştır. Öğretmen adaylarının arkadaşlık ilişkileri, sosyalleşme, şehre alışma, ögretim üyeleri, sinavlar ve dersler konularında sorun yaşayacaklarını düşündükleri belirlenmistir. Genel programda bilgilendirme etkinliklerinin fazla olduğu, etkinliklerin faydalı ve ĕglenceli ancak sıkıcı olduğu; tanışma etkinliğinin arkadaş ortamına

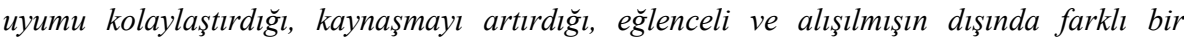
uygulama olduğu; program oryantasyon etkinliğinin faydall, bilgilendirici, stresi azaltıcı ve yapılmasının gerekli olduğu belirlenmiştir.

Anahtar Kelimeler: Fen bilimleri, oryantasyon, öğretmen adayı

\section{Investigation of Pre-Service Science Teachers Views on Orientation Program}

\begin{abstract}
This research aims to examine the pre-service science teachers' views about the orientation program. The phenomenological research was adopted in the research. 13 teacher candidates who participated in all orientation programs were studied. The data were collected through an open-ended interview form. The content analysis method was used in the analysis of the data. It was determined that pre-service teachers think that they will experience difficulties in friendship relations, socialization, getting used to the city, faculty members, exams and lessons. In the general program, information activities are high, activities are useful and fun but boring; the meeting activity facilitates adaptation to the friend environment, increases the fusion, and is a fun and unusual application; It was determined that program orientation activity is useful, informative, stress-relieving and necessary. It has been determined that orientation activities are fun, useful and informative, ensuring compliance with the environment and making friends.
\end{abstract}

Keywords: Science, orientation, pre-service teacher

\footnotetext{
* Atatürk Üniversitesi, Kazım Karabekir Eğitim Fakültesi, Matematik ve Fen Bilimleri Eğitimi Bölümü, Fen Bilgisi Eğitimi AD, Erzurum, Türkiye, emre.yildiz@ atauni.edu.tr, ORCID: 00000001-6396-9183 (D)

*** Atatürk Üniversitesi, Kazım Karabekir Eğitim Fakültesi, Matematik ve Fen Bilimleri Eğitimi Bölümü, Fen Bilgisi Eğitimi AD, Erzurum, Türkiye, yeterunlu@atauni.edu.tr, ORCID: 0000 $00034995828 \mathrm{X}$

Kaynak Gösterme: Yıldız, E., \& Ünlü, Y. (2021). Fen bilimleri öğretmen adaylarının oryantasyon programına yönelik görüşlerinin incelenmesi. Bayburt Eğitim Fakültesi Dergisi, 16(32), 395-409.
} 


\section{Giriş}

Bireyler aşina oldukları ortam veya durum değiştiğinde, kişiye göre değişen birçok zorluk veya sıkıntıyla karşılaşabilir. Genelde bu zorluk ve sıkıntılar fiziksel, sosyal, mekânsal, akademik ve yeni kurallar açısından yaşanmaktadır. Bireylerin bu yeni yani aşina olmadıkları ortam veya duruma alışmalarını kolaylaştırmak adına yardımcı olunması uyum sürecinin daha rahat atlatılmasını sağlayacaktır.

Bireylerin yeni ortama, duruma, işe ya da okula uyumunu kolaylaştırmak onlar için yeni olan duruma alışmalarını kolaylaştırmak için yapılan faaliyetlerin tümüne oryantasyon adı verilir. Oryantasyon kelimesi, Fransızca kökenli bir kelime olup yönelme, çevre şartlarına uydurma veya uyma, alışma, yeni bir çevreye alıştırma programı anlamına gelmektedir (Kafalı, 2011). Her yeni başlangıç bireyde duygusal, sosyal ve akademik olarak birçok değişimi beraberinde getirmektedir (Ceyhan, 1995; Sevinç \& Gizir, 2014; Yeşilyaprak, 2012). Bireyin içinde bulunduğu duruma uyum sağlaması, bireyin hem kendisiyle hem de içinde yaşadı̆̆ 1 toplum ve çevreyle bir ilişki kurarak ihtiyaçlarını karşılayabilmesi, bu ilişkiyi devam ettirebilmesi açısından oldukça önemlidir (Özgüven, 1992; Yeşilyaprak, Temuroğlu \& Ekşisu, 2014).

Lise öğrenimini tamamladıktan sonra üniversiteye geçiş bireylerin hayatında önemli bir andır. Üniversiteyi kazanmak ve üniversite hayatını yaşamak, çoğu kişinin hayallerinde olan ve beklenilen bir yaşam dönemidir. Üniversite yaşamına yeni başlayan öğrenciler farklı ve yabancı yeni bir durum içerisine girmektedir (Jackson Pancer, Pratt \& Hunsberger, 2000). Bu yeni durum özellikle ilk yılda gençlerin barınma, beslenme, ekonomik kaynakları kullanma, kültürel farklar ve bireyler tarafindan kabul edilme gibi konularda stres yaşamalarına neden olabilmektedir. Lise öğreniminden farklı olarak üniversite yaşamının getirmiş olduğu özgürlük ortamı, farklı arkadaşlıklar, öğrenci-öğretim üyesi ilişkileri ve mesleki dersler üniversite öğrenciliği yaşantısının yeni deneyimleri arasındadır (Kacur \& Atak, 2011). Öğrencilerin yeni öğretim ortamına uyum süreci sağlıklı bir şekilde gerçekleşmediği takdirde birçok psikolojik sorunlar yaşanabilmektedir (Clinciu, 2013). Bu psikolojik sorunların başında anksiyete, depresyon, stres, kırılganlık, öfke, akıl hastalıkları, negatif adaptasyon gelmektedir (Clinciu, 2013).

Bireylere verilecek oryantasyon eğitimi sayesinde yukarıda belirtilen sorunların ortaya çıkması önlenebilir (Aypay, Sever \& Demirhan, 2012; Bilici, 2016). Oryantasyon eğitimi, bireylerin yeni girdikleri ortamda karşılaşabilecekleri zorluk ve sıkıntıları en aza indirerek, yeni duruma alışmayı kolaylaştırmak, bireylerin kendilerini zayıf, çaresiz ve yalnız hissetmelerinin önüne geçmek amacıyla yapılmaktadır (Dolmac1 \& Duran, 2019; Kacur \& Atak, 2011; Yağc1, Ekinci, Burgaz, Kelecioğlu \& Ergene, 2007). Oryantasyon eğitimi; iletişimsizlik nedeniyle ortaya çıkabilecek yanlış anlaşılmalar, hatalar ve hoşnutsuzlukları engelleyen, bireylerin motivasyonlarını artıran, bireyleri yeni durumdaki görev, sorumluluk ve hakları hakkında bilgilendiren bir süreçtir (Aypay vd., 2012; Bulut \& Serin, 2016; Sertel, Yıldırım \& Akyol, 2017; Yeşilyaprak vd., 2014). 
Oryantasyona yönelik alanyazın incelendiğinde araştırmaların genellikle üniversite birinci sınıf öğrencilerinin uyum sorunlarının (Aladăg, Kağnıcı, Tuna \& Tezer, 2016; Aypay vd., 2012; Bulut \& Serin, 2016; Bülbül \& Güvendir, 2014; Dolmac1 \& Duran, 2019; Duru, 2016; Kacur \& Atak, 2011; Kafal1, 2011; Mercan \& Yıldız, 2011; Özkan \& Yılmaz, 2010; Sertel vd., 2017), yurtdışından gelen öğrencilerin uyum problemlerinin (Sarıtaş, Şahin \& Çatalbaş, 2016; Takır \& Özerem, 2019) ve yurt dışına giden öğrencilerin uyum problemlerinin incelenmesi (Bilici, 2016; Yağc1 vd., 2007) üzerine yoğunlaştı̆̆ görülmektedir.

Oryantasyona yönelik alanyazın çalışmaları incelendiğinde çalışmaların şu amaçlar doğrultusunda yapıldığı belirlenmiştir:

1. Üniversiteye yeni başlayan öğrencilerin üniversiteye başladıklarında en çok sorun yaşadıkları alanları belirlemek (Aladağ vd., 2016; Aypay vd., 2016),

2. Öğrencilerin üniversite bünyesinde verilecek psikolojik danışma ve rehberlik hizmetlerinden öncelikli olarak hangilerine ihtiyaç duyduklarının tespit edilmesi (Bülbül \& Güvendir, 2014; Duru, 2016),

3. Yükseköğretime yeni başlayan öğrencilerin uyum becerilerinde etkili olan faktörleri incelemek (Kacur \& Atak, 2011; Kafal1, 2011),

4. Üniversite öğrencilerinin akademik, psikolojik, sosyal, kültürel, ekonomik, sağlık, yaşam, iletişim, meslek edinme ve boş zamanı değerlendirme ile ilgili sorun alanlarının tespit edilmesi ve öğrencilerin bu sorunlarla baş etme yollarının belirlenmesi (Mercan \& Yıldız, 2011; Özkan \& Y1lmaz, 2010; Sertel vd., 2017),

5. Yabancı uyruklu öğrencilerin, okul ortamında yaşadıkları sorunları rehber öğretmen ve okul idarecileri gözünden ortaya koymak ve çözüm önerileri geliştirmek (Takır \& Özerem, 2019),

6. Kampüslerin öğrencilere sunduğu firsatları, öğrencilerin kampüste karşılaştıkları sorunları irdelemek ve daha iyi bir kampüsten (yerleşkeden) beklentilerini ortaya koyabilmek (Dolmacı \& Duran, 2019),

7. Erasmus programı ile yurt dışına giden öğrencilerin günlük yaşam, akademik yaşam ve öğrenci destek hizmetlerine ilişkin memnuniyet düzeylerini belirlemek (Yağcı vd., 2007),

8. Okullarında yabancı uyruklu öğrenci bulunan öğretmen ve yöneticilerin karşılaştıkları sorunları, sorunlara bulunan çözümler ve sorunlara yönelik çözüm önerilerini ortaya çıarmak (Sarıtaş vd., 2016)

$\mathrm{Bu}$ araştırmada alanyazın araştırmalarından farklı olarak öğretmen adaylarının gerçekleştirilen oryantasyon programına yönelik görüşlerinin incelenmesi esas alınmıştır. Bu araştırmada üniversite öğrenimine yeni başlayan fen bilimleri öğretmen 
adaylarının oryantasyon programına yönelik görüşlerini belirlemek amaçlanmıştır. Araştırmanın problem cümlesi: "Fen bilimleri öğretmen adaylarının oryantasyon programına yönelik görüşleri nelerdir?” şeklinde belirlenmiş olup araştırma kapsamında şu sorulara cevap aranmıştır:

1. Fen bilimleri öğretmen adayları üniversite hayatında ne tür sorunlar yaşayacaklarını düşünmektedirler?

2. Fen bilimleri öğretmen adaylarının düzenlenen oryantasyon programlarına yönelik görüşleri nelerdir?

3. Fen bilimleri öğretmen adaylarının oryantasyon programının yaşanacak olası sorunlara karşı ne derece fayda sağlayacağına yönelik görüşleri nelerdir?

\section{Yöntem}

Araştırmada olgu bilim deseni kullanılmıştır. Olgu bilim bireylerin yaşamış olduğu deneyimler üzerinde derinlemesine durmakta ve bu deneyimlerin kişiler için ne anlama geldiğine odaklanmaktadır (Creswell, 1998). Öğretmen adaylarının oryantasyon programına yönelik görüşlerinin ayrıntılı olarak belirlenmesi için bu araştırmanın amacına en uygun yöntem olması nedeniyle olgu bilim araştırması kullanılmıştır.

\section{Çalışma Grubu}

Araştırmanın çalışma grubunu 2019-2020 akademik yılında Atatürk Üniversitesi Fen Bilgisi Eğitimi programına kayıtlı 13 birinci sınıf öğretmen adayı oluşturmaktadır. "Kampüse Hoş Geldin" oryantasyon programı üniversite tarafından ve bölüm oryantasyon programı ve tanışma etkinliği danışman tarafından düzenlenmiştir. Çalışma grubuna oryantasyon programının tamamına eksiksiz olarak katılan öğretmen adayları dahil edilmiştir. Bu nedenle çalışma grubunun oluşturulmasında ölçüt örnekleme yönteminin kullanıldığı söylenebilir. Ölçüt örnekleme, örneklemin araştırma problemiyle ilgili olarak belirlenen özelliklere sahip kişiler, olaylar, nesneler ya da durumlardan oluşturulmasıdır (Patton, 2005). Düzenlenen tüm programlara katılma ölçütünü sağlayan 21 yeni kayıtlı birinci sınıf öğretmen adayından 16'sı araştırmaya katılmaya gönüllü olmuş ve bu öğretmen adayları arasından rastgele kura yöntemi ile 3 öğretmen adayı belirlenerek pilot uygulama yapılmıştır.

\section{Veri Toplama Araçları}

$\mathrm{Bu}$ araştırmada veriler beş adet açık uçlu sorudan oluşan görüşme formu ile elde edilmiş olup bu sorular iki fen bilgisi eğitimi, bir rehberlik ve psikolojik danışma ve bir ölçme değerlendirme alan uzmanının görüşüne sunulmuştur. Uzman görüşleri doğrultusunda 1 soru kökünde değişiklik yapılmış ve diğer sorular hazırlandığı şekliyle uygulanmıştır. Form ilk olarak belirlenen 3 öğretmen adayına uygulanıp pilot 
çalışması yapılmıştır. Pilot uygulama neticesinde formda farklı anlaşıılmalara neden olacak ifadelerin yer almadığı belirlenmiştir. Form öğretmen adaylarının üniversiteye başladıklarında yaşayacaklarını düşündükleri sorunlar, "Kampüse Hoş Geldin" programına yönelik görüşler, danışman tanışma etkinliğine yönelik görüşler, danışman oryantasyon etkinliğine yönelik görüşler ve düzenlenen etkinliklerin sorunlarına çözüm olup/olmama durumuna yönelik görüşlerini sorgulamaktadır.

\section{Verilerin Analizi}

Araştırma kapsamında toplanılan verilerin analizinde içerik analizi yönteminden faydalanılmıştır. Analizler yapılırken ilk olarak formdaki veriler öğretmen adaylarına kod atanarak hiçbir ifade değiştirilmeden yeniden yazılmıştır. Veriler tekrar tekrar okunarak yapısal kodlar oluşturulmuş benzer kodlar kategoriler altında birleştirilmiştir. Son olarak temalar oluşturulmuştur (Fraenkel, Wallen \& Hyun, 2011; Neuman, 2014). İşlemleri kolaylaştırmak adına veriler NVivo 12 Pro programına aktarılmış olup analizler program aracılığıyla gerçekleştirilmiştir.

Veriler iki araştırmacı tarafından birbirinden bağımsız olarak ve aynı araştırmacı tarafından iki farklı zamanda analiz edilmiştir. İki analiz arasındaki uyum yüzdesi;

$$
\text { Uyum yüzdesi }=\frac{\text { Uyum miktarı }}{\text { uyum miktarı }+ \text { uyuşmazlık miktarı }} \times 100
$$

formülü ile hesaplanmıştır. İki araştırmacı arasındaki uyum yüzdesi \%77 ve aynı araştırmacının iki farklı zamanda yaptığı analizler arasındaki uyum yüzdesi ise \%79 olarak bulunmuştur. Uyum yüzdelerinin $\% 70$ ve üzerinde olmas1 durumunda güvenirliğin sağlanmış olduğu söylenebilir (Miles \& Huberman, 1994).

\section{Uygulama}

\section{Kampüse Hoş Geldin oryantasyon programı}

Atatürk Üniversitesi 2019-2020 akademik yılı başlangıcında 3 gün süreyle üniversiteye yeni başlayan öğrenciler için oryantasyon etkinliği düzenlemiştir. Bu programda; üniversite yaşamına yönelik bilgilendirme yapmak amacıyla konferanslar, konserler, tiyatro gösterileri, kulüp tanıtımları, kütüphane ve merkezlerin tanıtımı, kampüs turu, şehir turu, sağlık, ulaşım, sportif ve kültürel faaliyet bilgilendirmeleri ve yurt yaşamına yönelik bilgilendirmeler gibi faaliyetler yer almıştır.

\section{Tanışma etkinliği}

Atatürk Üniversitesi Fen Bilgisi Eğitimi programına yeni başlayan öğretmen adayları için danışman tarafından tanışma etkinliği düzenlenmiştir. $\mathrm{Bu}$ etkinlikte öğrenciler ve programdaki öğretim üyeleri bir araya gelmiştir. Büyük bir halka oluşturulmuş ve bu sayede herkesin birbirini görmesi sağlanmıştır. İlk olarak herkes 
sırayla isminin başına isminin baş harfi ile başlayan ve kendini tanıtan bir sıfat getirerek ismini söylemiştir. Sonrasında bu faaliyete bir de kendilerini anlatan bir hareket ekleyerek tekrar edilmiştir. Etkinliğin bitiminde dörder kişilik gruplar oluşturulmuştur. Gruplardan kendilerine bir nesne belirlemeleri ve gruptaki herkesin o nesnenin bir parçası olması istenmiştir. Gruptaki bireyler tek tek seçtikleri nesnenin hangi parçası olduğunu diğer gruplara açıklamışlardır. Gruptaki tüm bireyler bittiğinde diğer gruplar bu grubun hangi nesne olduğunu tahmin etmeye çalışmıştır. Tüm gruplar tamamlandığında tanışma etkinliği sona ermiştir.

\section{Oryantasyon etkinliği}

Üniversitedeki genel programın aksine bu program yalnızca yeni başlayan birinci sınıf fen bilgisi öğretmen adaylarına uygulanmıştır. Oryantasyon etkinliğinde; bölüm, dersler, laboratuvar uygulamaları, sınav (vize-final ve bütünleme) sistemi, puan hesaplama, harf notları, not ortalaması hesaplamaları (agno), geçme-kalma ve yaz okulu hakkında bilgilendirmeler yapılmış, fakülte gezisi ile derslikler ve laboratuvarlar ziyaret edilmiştir.

\section{Bulgular}

\section{Birinci Araştırma Sorusuna Ait Bulgular}

Öğretmen adaylarının üniversite hayatında sorun yaşayacaklarını düşündükleri durumlar Tablo 1'de verilmiştir.

Tablo 1.

Üniversite Hayatında Yaşanılacağı Düşünülen Sorunlar

\begin{tabular}{lll}
\hline Tema & Kod & F \\
\hline Yeni Çevre Edinme & arkadaşlar & 5 \\
& sosyalleşme & 4 \\
& kültür & 1 \\
& düşünce & 2 \\
\hline Akademik Kaygılar & dersler & 5 \\
& sınavlar & 9 \\
& öğretim üyeleri & 10 \\
\hline Yeni Yaşam Şartlarına & yurt & 2 \\
Alışma & şehir & 3 \\
& aileden ayrılma & 1 \\
\hline
\end{tabular}

Tablo 1'de verilen analiz sonuçları incelendiğinde öğretmen adaylarının en fazla öğretim üyeleri ile ilgili sorun yaşayacaklarını düşündükleri belirlenmiştir. Öğretmen adaylarının sınavlar, dersler, arkadaş edinme, sosyalleşme ve şehre alışma konusunda endişe duydukları görülmektedir. Öğretmen adaylarının verdikleri cevaplara örnek olarak: 
ÖA-13: Ailemden uzak kalacă̆ım için özlem yaşayabileceğimi düşünüyordum. ...

ÖA-2: ... Bir de sınıfima ve arkadaşlarıma uyum sağlayamama gibi endişelerim vardl.

ÖA-7: Hocaların bana karşı çok sert tavırlı olacă̆ını önceden ögretmenlerimle olduğu gibi bir ilişkimin olmayacağını düşünüyordum.

\section{İkinci Araştırma Sorusuna Ait Bulgular}

Öğretmen adaylarının üniversitenin düzenlemiş olduğu "Kampüse Hoş Geldin" programına yönelik görüşleri Tablo 2'de verilmiştir.

Tablo 2.

Kampüse Hoş Geldin Oryantasyon Programına Yönelik Görüşler

\begin{tabular}{lll}
\hline Tema & Kod & $\mathrm{F}$ \\
\hline Üniversite Hayatına & tanıtım & 3 \\
Yönelik Bilgiler & bilgilendirme & 7 \\
& tavsiye & 2 \\
\hline Sosyalleşme & aktiviteler & 3 \\
& konserler & 1 \\
& kulüpler & 2 \\
& tanışma & 3 \\
\hline Olumlu Yönleri & eğlenceli & 5 \\
& faydalı & 4 \\
& bilgilendirici & 3 \\
& anlaşılır & 1 \\
\hline Olumsuz Yönleri & słkıcı & 9 \\
& zaman alıcı & 3 \\
\hline
\end{tabular}

Tablo 2'de verilen analiz sonuçlarına göre öğretmen adayları, üniversite hayatına yönelik bilgilendirme etkinliklerinin fazla olduğu, etkinliklerin faydalı ve eğlenceli ancak sıkıcı olduğu görüşündedir. Öğretmen adaylarının verdikleri cevaplara örnek olarak:

ÖA-5: Böyle bir etkinliğe ilk kez katıldım. Üniversite hakkında, Erzurum hakkında birçok bilgi edindim.

ÖA-3: Gündüz programları çok bilgilendirici, akşam programları da bir o kadar ĕglenceli. Bu programlarda birçok yeni arkadaş edindim. Çevrem genişledi.

ÖA-10: Beni en çok etkileyen düzenlenen şehir turlartydı. Bu kadar tarihi alan ve sosyalleşebileceğim alanların olduğunu hiç tahmin etmiyordum. 
Öğretmen adaylarının düzenlenen tanışma etkinliğine yönelik görüşleri Tablo 3’te verilmiştir.

Tablo 3.

Danışmanın Düzenlediği Tanışma Etkinliğine Yönelik Görüşler

\begin{tabular}{lll}
\hline Tema & Kod & F \\
\hline Tanışma/Kaynaşmayı & uyum & 4 \\
Kolaylaştırması & kaynaşma & 3 \\
& iletişim & 2 \\
& önyargı & 6 \\
\hline Olumlu Yönleri & farklı uygulama & 3 \\
& eğlenceli & 4 \\
& kalıcı & 2 \\
\hline
\end{tabular}

Tablo 3'te verilen analiz sonuçlarından görüldüğü üzere öğretmen adayları tanışma etkinliğinin bireyler arasındaki önyargıları ortadan kaldırdığı, arkadaş ortamına uyumu kolaylaştırdığı, kaynaşmayı artırdığı, eğlenceli ve alışılmışın dışında farklı bir uygulama olduğu görüşündedir. Öğretmen adaylarının verdikleri cevaplara örnek olarak:

ÖA-9: Dersler başlamadan önce sınıf arkadaşlarımı ve hocalarımı tanışma firsatı buldum. Arkadaşlık ilişkilerimin bu kadar çabuk ve rahat gelişebileceğini hiç sanmazdım.

ÖA-1: Benim için çok yeni hiç görmediğim bir uygulamaydl.

ÖA-6: Gelmeden önce hocaların böyle olabileceğini hiç düşünmüyordum. Bizimle çok mesafeli çok disiplinli olacaklarını sanıyordum ama sıcak samimi bir tanısmamız oldu.

Öğretmen adaylarının danışman tarafından düzenlenen oryantasyon programına yönelik görüşleri Tablo 4'te verilmişstir.

Tablo 4.

Danışmanın Düzenlediği Oryantasyon Programına Yönelik Görüşler

\begin{tabular}{lll}
\hline Tema & Kod & F \\
\hline Olumlu yönleri & faydalı & 3 \\
& bilgilendirici & 6 \\
& stresi azaltıcı & 4 \\
\hline Programın Gerekliliği & gerekli & 3 \\
\hline
\end{tabular}

Tablo 4'te verilen analiz sonuçlarından görüldüğü üzere öğretmen adayları programın faydalı, bilgilendirici, stresi azaltıcı ve yapılmasının gerekli olduğu görüşündedir. Öğretmen adaylarının verdikleri cevaplara örnek olarak:

ÖA-11: Bence iyi bir uygulama yaptı. Okula yeni gelen birinin korkularını, streslerini atması için çok güzel bir uygulamaydı. ... 
ÖA-4: Gelmeden önce merak ettiğim, kafamda olan soruların hepsine cevap aldiğım bir etkinlik oldu. ...

ÖA-8: ... Okuduğum bölümü tanımamda derslerim, sınavlarım, notlar, geçme-kalma, hocalar gibi benim için oldukça yararlı oldu.

\section{Üçüncü Araştırma Sorusuna Ait Bulgular}

Öğretmen adaylarının oryantasyon programının yaşanacak olası sorunlara karşı çözüm olmasına yönelik görüşleri Tablo 5 'te verilmiştir.

Tablo 5 .

Oryantasyon Programlarının Yaşanacak Olası Sorunlara Çözüm Olmasına Yönelik Görüşler

\begin{tabular}{lll}
\hline Tema & kod & $\mathrm{F}$ \\
\hline Sosyalleşme & uyum & 5 \\
& arkadaş edinme & 4 \\
\hline Faydaları & gerekli & 2 \\
& eğlenceli & 4 \\
& faydalı & 6 \\
& bilgilendirici & 9 \\
\hline Olumsuzluklar & kalabalık & 3 \\
& yetersiz & 2 \\
\hline
\end{tabular}

Tablo 5'te verilen analiz sonuçlarından öğretmen adaylarının programın ortama uyumu ve arkadaş edinmeyi sağladığı, eğlenceli, faydalı ve bilgilendirici olduğu, ancak etkinliklerin çok kalabalık olduğu ve bazı alanlarda yetersiz kaldığ düşüncesinde oldukları görülmektedir. Öğretmen adaylarının verdikleri cevaplara örnek olarak:

ÖA-10: İyiydi ama çok kalabalıktı. Bütün 1. sınıflar aynı günde ve her gün gelince çok yoğun oldu. ...

ÖA-2: ... Birçok fakülteden insanlar vardı. Onlarla tanışmamda çevre edinmemde çok iyi oldu.

ÖA-Ailemden ilk kez bu kadar uzun ayrı kaldığım için çok kötüydüm sürekli ă̆lıyordum. Ama çok güzel etkinlikler vardl. Eğlendim ve moralim biraz olsun yerine geldi. ...

\section{Tartışma, Sonuç ve Öneriler}

Çalışmanın sonucunda öğretmen adaylarının arkadaşlık ilişkileri, sosyalleşme, şehre alışma, öğretim üyeleri, sınavlar ve dersler konularında sorun yaşayacaklarını düşündükleri belirlenmiştir. Üniversitede farklı bölgelerden bireylerin bir araya gelmesi nedeniyle öğretmen adayları arasında kültürel farkların olması, farklı düşünce yapıları gibi nedenlerle ilk kez girecekleri ortamda arkadaş edinme, yabancı oldukları 
bir şehirde yeni bir yaşam düzeni oluşturma, öğretim üyelerinin sert, anlayışsız, katı kuralları olan bireyler çıkması, ders işleme tarzlarının lisede alıştıkları düzenden farklı olması, sınavların alıştıkları çoktan seçmeli türden açık uçlu klasik tarza dönüşmesi, sınavların çok zor olması, sınavlara hazırlanmanın çok zaman alması, derslerin zor olması, kendilerine düşen iş yükünün fazla olması gibi korkuları yüzünden üniversite hayatına başlangıçta zorluk yaşayacaklarını düşündükleri söylenebilir. Yapılan birçok araştırmada da bu araştırma sonuçlarına benzer şekilde dersler, sosyo-kültürel ortam, arkadaşlık ilişkileri gibi konularda uyum problemlerinin yaşandığ belirtilmektedir (Aladağ vd., 2016; Dolmacı \& Duran, 2019; Kacur \& Atak, 2011; Özkan \& Y1lmaz, 2010; Mercan \& Yıldız, 2011; Yağc1 vd., 2007).

Öğretmen adaylarının "Kampüse Hoş Geldin" oryantasyon programı hakkında üniversite hayatına yönelik bilgilendirme etkinliklerinin fazla olduğu, etkinliklerin faydalı ve eğlenceli ancak sıkıcı olduğu görüşünde oldukları belirlenmiştir. Etkinliğin konferanslarda üniversite yaşamına yönelik bilgilendirmelerin yapılması, üniversitenin ve üniversitede yürütülen faaliyetlerin tanıtılması, hastane, yurt, ulaşım, sosyal, kültürel ve sportif faaliyetlerin tanıtılması, kampüs ve şehir turlarının yapılması nedeniyle bilgilendirici ve faydalı olduğu, konferansların tek yönlü olması nedeniyle bilgilendirme faaliyetlerinin sıkıc1 olduğu, konser ve tiyatro organizasyonlarının etkinliği renklendirdiği ve öğretmen adaylarını eğlendirdiği söylenebilir.

Öğretmen adaylarının tanışma etkinliğinin arkadaş ortamına uyumu kolaylaştırdığı, kaynaşmayı artırdığı, eğlenceli ve alışılmışın dışında farklı bir uygulama görüşünde oldukları belirlenmiştir. Etkinlikte öğretmen adayları ve öğretim üyelerinin birlikte olması, bireylerin kendilerini en iyi anlatan bir sıfat ve hareket kullanarak tanıtmaları, birlikte bir nesne seçmeleri ve nesnenin parçalarını paylaşmaları, birlikte tahminlerde bulunmaya çalışmalarının eğlenmelerini sağladığı, bireyler arasındaki uyumu artırdığı, tanışmanın daha kalıcı olduğu ve öğretim üyeleri hakkındaki önyargıları kırdığ s söylenebilir. Benzer şekilde oryantasyon programlarının bireylerin birbirini tanımasını, sosyalleşmesini ve arkadaş edinmeyi kolaylaştırdığı alanyazındaki araştırmalarda belirtilmiştir (Dolmacı \& Duran, 2019, Mercan \&Yıldız, 2011; Özkan \& Yılmaz, 2010; Pancer, Hunsberger, Pratt \& Alisat 2000; Sertel vd., 2017).

Öğretmen adaylarının danışman öğretim elemanı tarafindan öğretmen adaylarına hazırlanan oryantasyon programının faydalı, bilgilendirici, stresi azaltıcı ve yapılmasının gerekli olduğu görüşünde olduğu belirlenmiştir. Etkinlik içeriğinde öğretmen adaylarının okuyacakları programla ilgili en fazla ihtiyaç duydukları dersler, sınavlar, harf notları, agno, geçme-kalma, yaz okulu gibi bilgileri içermesi nedeniyle faydalı, bilgilendirici, kaygıyı azaltıcı ve yapılmasının gerekli olduğu söylenebilir

Öğretmen adaylarının programın ortama uyumu ve arkadaş edinmeyi sağladığı, eğlenceli, faydalı ve bilgilendirici olduğu, ancak etkinliklerin çok kalabalık olduğu ve 
bazı alanlarda yetersiz kaldığı düşüncesinde oldukları belirlenmiştir. Etkinliklerde öğretmen adaylarının birbirleri ve öğretim üyeleri ile tanışma ve kültürel faaliyetlerde farklı fakültelerden farklı bölümlerden bireylerle tanışma durumlarının sosyalleşme düzeyini artırdığı ve arkadaş edinmeyi kolaylaştırdığı, üniversite hayatına yönelik konferansların ve program tanıtımının bilgilendirici ve faydalı olduğu ancak üniversitenin düzenlediği organizasyona tüm fakültelerden katılımın olması nedeniyle kalabalık olduğu ve tüm fakültelere yönelik düzenlendiği için genel olduğundan bazı özel alanlarda yetersiz kaldığı söylenebilir (Aypay vd., 2012). Alanyazında yapılan araştırmalarda bu araştırma sonuçlarına benzer şekilde uyum programlarının ortama uyumu kolaylaştırdığı, arkadaş edinmeyi sağladığı ve faydalı olduğu belirtilmektedir (Alpan, 1992; Bülbül \& Güvendir, 2014; Erdoğan, Şanlı \& Bekir, 2005; Kafalı, 2011; Kolunsağ \& Özdemir, 2007; Mercan \&Yıldız, 2011; Şen, 2004).

Üniversite yaşamı öğrencilerin hayatlarında büyük öneme sahip olan yeni bir başlangıçtır (Eren \& Kılıç, 2014). Bireylerin bu yeni başlangıcı sorunsuz bir şekilde gerçekleştirmesinde uyum programları büyük bir öneme sahiptir. Üniversiteye yeni başlayan bireyler için uyum programlarının hazırlanması bu konuda yararlı olabilir. Üniversite yaşamı süresince bireyler birçok farklı durumla karşılaşabilmektedir. $\mathrm{Bu}$ nedenle uyum programları yalnızca başlangıçta bir kez yapılıp tamamlanan bir şekilden ziyade üniversite yaşamı süresince devam eden programlar şeklinde düzenlenmelidir. Bireylerin geçmiş yaşantılarının yeni duruma uyumlarına etkisi incelenebilir.

\section{Çıkar Çatışması ve Etik Bildirimi}

Yazarlar arasında çıkar çatışması bulunmadığını ve tüm araştırmacıların çalışmaya eşit oranda katkı sunduğunu beyan ederim. Makalenin yazarı olarak, bu makalede bilimsel ve etik kurallara uyulduğunu beyan ederim.

\section{Kaynakça}

Aladağ, M., Kağnıcı, D.Y., Tuna, M.E., \& Tezer, E. (2016). Üniversite yaşamı ölçeği: ölçek geliştirme ve yapı geçerliliği üzerine bir çalışma. Türk Psikolojik Danışma ve Rehberlik Dergisi, 2(20), 41-47.

Alpan, A. (1992). Cumhuriyet Üniversitesi ve Erciyes Üniversitesi fen edebiyat fakültesi ögrencilerinde çevreye ve üniversiteye uyum sorunları (Tez No. 22506) [Yüksek lisans tezi, Cumhuriyet Üniversitesi-Sivas]. Yükseköğretim Kurulu Başkanlığı Tez Merkezi.

Aypay, A., Sever, M., \& Demirhan, G. (2012). Üniversite öğrencilerinin sosyal ve akademik entegrasyonu: Boylamsal bir araştırma. Gaziantep University Journal of Social Sciences, $11(2), 407-422$.

Bilici, N. (2016). Erasmus programı çerçevesinde Türkiye'den yurtdışına giden ve yurtdışından Türkiye'ye gelen yabancı öğrencilerin sosyal uyumlarının karşılaştırmalı incelenmesi (Tez No. 435237) [Yüksek lisans tezi, Haliç Üniversitesi-İstanbul]. Yükseköğretim Kurulu Başkanlığ Tez Merkezi.

Bulut, C., \& Serin, N.B. (2016). Öğretmen adaylarının üniversite yaşamına uyum düzeyleri ile yaşam doyumu arasındaki ilişkinin incelenmesi. International Journal of New Trends in Arts, Sports \& Science Education (IJTASE), 5(4), 616-623. 
Bülbül, T., \& Güvendir, M.A. (2014). Üniversite birinci sınıf öğrencilerinin yükseköğretim yaşamına uyum düzeylerinin incelenmesi. Eğitim Bilimleri Araştırmaları Dergisi, 4(1), 397-418.

Ceyhan, E. (1995). Oryantasyon eğitimi. Yaşadıkça Ĕ̆itim Dergisi, 42, 14-15.

Clinciu, A.I. (2013). Adaptation and stress for the first year university students. Procedia Social and Behavioral Sciences, 78, 718-722.

Creswell, J.W. (1998). Qualitative inquiry and research design: Choosing among five traditions. Sage.

Dolmac1, N., \& Duran, Y. (2019). Ön lisans öğrencilerinin kampüs yaşamından beklentileri ve karşılaştıkları sorunlar: Isparta meslek yüksekokulu grafik tasarım programı örneği. Akademik Bakış Uluslararası Hakemli Sosyal Bilimler Dergisi, 71, 149-156.

Duru, E. (2016). Üniversiteye uyum sürecinde yalnızlığ 1 yordamada sosyal destek ve sosyal bağl1lığın doğrudan ve dolaylı rolleri. Türk Psikolojik Danışma ve Rehberlik Dergisi, 3(29), 13-24.

Erdoğan, S., Şanlı, H.S., \& Bekir, Ş.H. (2005). Gazi Üniversitesi eğitim fakültesi öğrencilerinin üniversite yaşamına uyum durumları. Kastamonu Ĕ̈itim Dergisi. 13(2), 479-496.

Eren, H., \& K1lıç, A. (2014). Yenilikçilik açısından üniversite öğrencilerinin ortamı. Turkish Journal of Social Research/Turkiye Sosyal Araştırmalar Dergisi, 18(3), 51-78,

Fraenkel, J.R., Wallen, N.E., \& Hyun, H.H. (2011). How to design and evaluate research in education (8 th ed.). McGraw-Hill.

Jackson, L.M. Pancer, S. M. Pratt, M.W. \& Hunsberger, B.E.(2000). Great expectations: the relation between expectancies and adjustment during the transition to university. Journal Of Aplied Social Psychology, 30(10), 2100-2125.

Kacur, M., \& Atak, M. (2011). Üniversite öğrencilerinin sorun alanlar ve sorunlarla başetme yolları: Erciyes üniversitesi örneği. Erciyes Üniversitesi Sosyal Bilimler Enstitüsü Dergisi, 2(31), 273-297.

Kafalı, E. (2011). Yükseköğretime yeni başlayan öğrencilerin uyum becerilerini etkileyen faktörlerin değerlendirilmesi (Tez No. 297642) [Yüksek lisans tezi, Namık Kemal Üniversitesi-Tekirdağ]. Yükseköğretim Kurulu Başkanlığı Tez Merkezi.

Kolunsağ, A., \& Özdemir, G. (2007). Sürdürülebilir oryantasyon modeli ve Sakarya Üniversitesi'ndeki durum. Sakarya Üniversitesi Eğitim Fakültesi Dergisi, 14, 211-229.

Mercan, Ç.S., \& Yıldız, S. (2011). Eğitim fakültesi birinci sınıf öğrencilerinin üniversiteye uyum düzeylerinin farklı değişkenler açısından incelenmesi. HAYEF Journal of Education, 8(2), 135-154.

Miles, M.B. \& Huberman, A.M. (1994). Qualitative data analysis: an expande sourcebook. (2nd edition). Sage.

Neuman, W.L. (2014). Toplumsal araştırma yöntemleri: Nitel ve nicel yaklaşımlar (S. Özge, Çev.). Yayın Odası.

Özgüven, İ.E. (1992). Üniversite öğrencilerinin sorunları ve baş etme yolları. Hacettepe Üniversitesi Ĕgitim Fakültesi Dergisi, 7(7), 5-13.

Özkan, S., \& Yılmaz, E. (2010). Üniversite öğrencilerinin üniversite yaşamına uyum durumları (Bandırma örneği). Fırat Să̆llk Hizmetleri Dergisi, 5(13), 153-171.

Pancer, S.M., Hunsberger, B., Pratt, M.W., \& Alisat, S. (2000). Cognitive complexity of expectations and adjustment to university in the first year. Journal of Adolescent Research, 15(1), 38-57.

Patton, M. Q. (2005). Qualitative research. John Wiley \& Sons, Ltd.

Sarıtaş, E., Şahin, Ü., \& Çatalbaş, G. (2016). İlkokullarda yabancı uyruklu öğrencilerle karş1laşlan sorunlar. Pamukkale Üniversitesi Sosyal Bilimler Enstitüsü Dergisi, (Ek1), 208-229. 
Sertel, E., Yıldırım, H., \& Akyol, S.Ö. (2017). Meslek yüksekokulu öğrencilerinin okul tercih sebepleri ve uyum durumları: Sivrihisar örneği. Mehmet Akif Ersoy Üniversitesi Sosyal Bilimler Enstitüsü Dergisi, 9(21), 101-117.

Sevinç, S., \& Gizir, C.A. (2014). Üniversite birinci sınıf öğrencilerinin bakış açılarından üniversiteye uyumu olumsuz etkileyen faktörler (Mersin Üniversitesi Örneği). Kuram ve Uygulamada Ĕ̌itim Bilimleri Dergisi, 14(4), 1285-1308.

Şen, Ö.Ö. (2004). Ege Üniversitesi Eğitim Fakültesi öğrencilerinin sorunlarının bazı değişkenler açısından incelenmesi (Tez No. 146217) [Yüksek lisans tezi, Ege Üniversitesiİzmir]. Yükseköğretim Kurulu Başkanlığı Tez Merkezi.

Mercan, Ç.S., \& Yıldız, S.A. (2011). Eğitim fakültesi birinci sınıf öğrencilerinin üniversiteye uyum düzeylerinin farklı değişkenler açısından incelenmesi. HAYEF Journal of Education, 8(2), 135-154.

Takır, A., \& Özerem, A. (2019). Göçle gelen yabancı uyruklu öğrencilerin okul ortamında karşılaştıkları sorunlar. Folklor/Edebiyat, 25(97), 639-657.

Yağcı, E., Ekinci, C.E., Burgaz, B., Kelecioğlu, H., \& Ergene, T. (2007). Yurt dışına giden Hacettepe Üniversitesi Erasmus öğrencilerinin memnuniyet düzeyleri. Hacettepe Üniversitesi Ĕ̈itim Fakültesi Dergisi, 33(33), 229-239.

Yeşilyaprak, B. (2012). Ĕgitimde rehberlik hizmetleri (20. Basım). Nobel Akademik Yayıncilik.

Yeşilyaprak, B., Temuroğlu, S.Y., \& Ekşisu, M. (2014). Ortaöğretime uyum programı pilot uygulama ve değerlendirme raporu.

\section{Extended Abstract}

Individuals may experience many difficulties or troubles depending on the individual when the environment or situation they are familiar with changes. In general, these difficulties and troubles are experienced in terms of physical, social, spatial, academic and new rules. When the environment or situations in which they are accustomed to individuals change, being a half-man to facilitate they're getting used to this new environment or situation that they are not familiar with will enable the adaptation process to be overcome more easily.

After completing high school education, the transition to university is an important moment in individuals' lives. Winning the university and university life is a life expectancy that most people dream of. Students who have just started their university life are entering a new and different situation. Housing, nutrition, the use of economic resources, cultural differences and the need to be accepted by other individuals, etc. issues can cause intense stress in the first years.

Thanks to the orientation training to be given to individuals, the emergence of such problems can be prevented. Orientation training is carried out to minimize the difficulties and difficulties that individuals may encounter in their new environment, to make it easier to get used to the new situation and to prevent individuals from feeling weak, helpless and lonely. Orientation training; It is a process that prevents misunderstandings, mistakes, and discontent that may arise due to communication, increases the motivation of individuals and informs individuals about their duties, responsibilities, and rights in the new situation. 
In this study, it is aimed to determine the opinions of science teacher candidates who have just started their university education towards the orientation program. Problem status of the research: "What are the views of prospective science teachers towards the orientation program?" It was determined as. Within the scope of the research, answers to the following questions were sought:

1. What kind of problems/difficulties do prospective science teachers think they will experience in university life?

2. What are the views of prospective science teachers towards the orientation programs organized?

3. What are the views of prospective science teachers towards the solution of the problems they think they will experience in the orientation program?

The case study was used in the research. Generally, "How?" or "Why?" It has been preferred because it is the most suitable method for the research and the problem situation, because of seeking answers to questions and studying in real-life situations that cannot be controlled. The study group of the research consists of 13 first-year preservice teachers enrolled in the Atatürk University Science Education Program in the 2019-2020 academic year. Only the "Welcome to the Campus" orientation program organized by the university, the teacher activity organized by the supervisor and teacher candidates who participated in all of the orientation programs were included in the study group. In the study, the data were obtained through an open-ended interview form.

Content analysis method was used in the analysis of research data. In the analysis, first of all, the data in the form were rewritten by assigning code to prospective teachers without changing any expression. The data are read over and over again, and structural codes are created. Codes are assigned to the relevant sections in the data. Similar codes are combined under categories. Finally, themes have been created. The data were analyzed by the same researcher at two different times. The percentage of agreement between the two analyzes was calculated as $79 \%$. The data were also analyzed independently from the first researcher by the second researcher, and the compatibility between the two researchers was calculated as 0.76 with Cohen's Kappa coefficient through the SPSS 20 package program.

It was determined that pre-service teachers think that they will experience difficulties in friendship relations, socialization, getting used to the city, faculty members, exams and lessons.

It has been determined that the pre-service teachers' information about the "Welcome to Campus" orientation program is high in university life and that the activities are useful and fun but boring. 
It was determined that teacher candidates' meeting activity facilitated adaptation to friend environment, increased cohesion, and they had a different view of practice.

It has been determined that teacher candidates think that the orientation program prepared by the counselor is useful, informative, stress-relieving and necessary.

It has been determined that pre-service teachers think that the program provides adaptation to the environment and making friends, is fun, useful and informative, but the activities are too crowded and inadequate in some areas.

University life is a new beginning that has great importance in students' lives. Adaptation programs are of great importance for individuals to realize this new beginning without any problems. The preparation of adaptation programs for individuals who are new to the university can be useful in this regard. Also, individuals may encounter many different situations during their university life. For this reason, adaptation programs should be organized as programs that continue during the life of the university, rather than a form that is completed and completed only once. 